\title{
Scientific Advancement in Contemporary Society: The Interface between Technology, Science and Law
}

\author{
Adetutu D. Aina-Pelemo, PhD \\ Department of Law, Redeemer's, University, Ede, Osun-State, Nigeria \\ Ananya P. Patil, \\ Department of Law, Sharda University, Greater-Noida, Uttar Pradesh, India
}

Paul A. Ejembi, PhD

Department of Law, Legacy University, Banjul, The Gambia

Sandra F. Oloketuyi,

Department of Biotechnology, University of Nova Gorica, Slovenia

Aina I. T.,

Department of Law, Afe Babalola University, Ado-Ekiti, Nigeria

Doi:10.19044/esj.2019.v15n32p127 URL:http://dx.doi.org/10.19044/esj.2019.v15n32p127

\begin{abstract}
This article is premised on the relation of technology and applied sciences with law. The three subjects are not only interwoven but cannot be protected and regulated without the viable use of law. The unprecedented advancement of scientific innovations has far-reaching implication in virtually all ramifications of human endeavour. Technology is an invention created using science, which needs to be sustained by prudent management and law. The research goal is to narrow down a middle ground where all these independent fields can meet and share a symbiotic relationship without stifling each other. The research seeks to ascertain the knowledge and perception of selected university students of Nigeria and India, about Science, Law and Technology. The authors adopted the doctrinal and empirical research methodology coupled with the use of cases and legislations as source of information. The research revealed that majority of the participants has knowledge about the co-existence and impact of Science, Technology and Law in the society. However, the attitude and perception of the participants constitute a fundamental influence on the degree to which technological orientations occur during learning process. Also, 85\% of 200 participants agreed that there is need for frequent education and legislation as science and technology evolves in the society. Hence, this article recommends the implementation and frequent modifications of law to continually protect, encourage and ensure the societal sustainability of ethical standards.
\end{abstract}


Keywords: Advancement, Law, Relations, Science, Sustainability, Technology

\section{Introduction}

The $21^{\text {st }}$ Century is characterised by unprecedented developments in the field of science and technology. The unbridled advancement of scientific innovations has had far-reaching implications in virtually all ramifications of human endeavour. It has been asserted that;

Art, in its legal significance, embraces every operation of human intelligence, whereby something is produced outside of nature; and the term 'science' includes all human knowledge which has been generalised and systematised, and has obtained method, relations and the forms of law (Atchison and C.R.R. Co. v. U.S., 1971).

In other words, everything known to man, about the material world is science and when such knowledge is applied, it is given the name 'technology'. Such knowledge, at its apex, forms the ideal foundation to a Utopian political system and when utilised to govern human interactions and relationships, becomes the law of the land (Bakshi, 1995). This denotes that science and technology affect the society, while law reflects the changes in the society, as well as ensure the legitimacy of such changes. Therefore, law as a subject, is dynamic and ever-evolving, acting as a mirror for the constant developments of the society (Dellapenna, 2000). Meanwhile, legal scholars have just recently started taking cognisance of the inherent relationship that law and technology share (Bernstein, 2004). To some extent, they only speak or write about it as an object of fascination (Beebe, 1999).

Today, while it is the local and international companies, laboratories and public research institutions that study science and create technology (Albert and Laberge, 2007), its development and evolution largely still depends on economics, law, politics and culture (Weiss, 2005). Although law and science have achieved unprecedented hegemony, both recognised and claimed to be limited by their own fields of action. In science, the limits are co-extensive with the scientific method of inquiry; while in law, the limits reside in procedural technicalities (Silbey, 2008). Another issue is that law and science have long been represented as two fundamentally different enterprises, which gives rise to two stark realities: on the one hand, there will always be an unavoidable culture clash between the practitioners of law and science respectively and on the other hand, law will continually imbibe the culture of science, while adjudicating upon scientific issues (Jasanoff, 1995). However, one can also not ignore the exorbitant cost and inefficiency of the judicial process, which prompts a concern about the role of courts in shaping 
technology policy. Legal relief for technological mishaps is neither cheap nor speedy.

In complex cases, the expense of producing evidence and hiring expert witnesses adds significantly to the initial heavy burden of attorneys' fees and court costs (Jasanoff, 1995). Nevertheless, it is universally and quite understandably accepted that science develops and grows primarily, while law keeps up with it, though at a varying pace. This is probably so, because law carries the weight of policies, human beings and the society, unlike science, where the answers usually fall within a black or white area. It would therefore be beneficial multi-fold, if the two fields were to meet in the middle, where there is maximum scope for the growth and advancement of both, without stifling the interests of the other (Feldman, 2009). Likewise, if law and technology were no more than a series of discussions about legal problems involving a new gadget or technique, then 'law and technology' amounts to nothing more than the law of the horse (Easterbook, 1996). If, however, law and technology can be thought of as series of related problem that law frequently confronts in situations where technology changes, then the focus on law and technology as an area of study is justified (Moses, 2007).

Having considered the relations of technology and applied sciences with law and the far reaching implications of unprecedented advancement of scientific innovations in human endeavour specifically in India and Nigeria, for example, the use of phone while driving, walking, and cooking, doing house chores, teaching and receiving lectures in schools, cybercrime rates and consequences of such act to the society. This prompted the need to examine the vitality of the role of law and legal education as it relates to creativity, inventions, security and sustainability for future generations. This study examines the disadvantages of those advances in technologies as it relates to law and society, as well as the symbiotic relationships of science, technology and law and the middle ground where they can meet without stifling one another. The target population group (university students) and countries were selected for the survey due to the population, proximity of the authors with the participants, and the similarities in the legal system of the regions, as they both operate on common law system (Aina-Pelemo et al., 2018; Aina-Pelemo and Saluja, 2018).

\section{Research Methodology}

The research instrument (questionnaire) comprises of fifteen (15) opened-ended, closed-ended and multiple-choice questions; the first ' 4 ' questions centered on demographic information, the second session was based on the relationship between Science, Technology and Law and the third session dealt with the dependence and effect of Science and Technology on Law. 
A total of 200 responses from selected university students in National Capital Region (NCR), India and Federal Capital Territory, (FCT) Nigeria were collected using a structured questionnaire that was disseminated through simple random sampling via Google drive.

The filled questionnaires were arranged and decoded. Data analysis such as frequency, ANOVA, correlation and cross-tabulations was done by the use of Statistical Package for Social Sciences (SPSS Version 24, IBM) software. The descriptive survey and ex post facto research designs adopted for this study involves- empirical, exploratory and comparative research methodologies (Aina-Pelemo and Saluja, 2018). Descriptive survey research centres on people, attitude, belief, motivation, behaviour and opinions (Osuala, 2007). Expo-facto research design aims at obtaining important information on the status of specific phenomenon after some naturally occurring treatment without any manipulation of the situation. Additional information was sourced by studying existing papers, journal, articles, online database, with the support of various cases, sections and legislations (AinaPelemo et al., 2018).

\section{Ethical approval}

All procedures performed in this study involving human participants were in accordance with the ethical standards of the Research, Training and Development Center of Sharda University and with the 1964 Helsinki declaration and its later amendments. Informed consent was obtained from all individual participants with explanation of the purpose of the study, willingness to share the information prior to data collection and introduction of the questions accordingly.

\section{Research Objective:}

- What is the knowledge and perception of selected university students of Nigeria and India, about Science, Law and Technology?

\section{Hypotheses}

1. There is no significant difference between male and female's awareness of science, Technology and law.

2. Science, Technology and Law influence and depend on each other.

3. Science, Technology and Law do not co-exist harmoniously in the society.

4. The impact of Science, Technology and Law in the society is significant.

The survey was conducted among 200 participants that consisted of $55.5 \%$ male and $45.5 \%$ female, mostly between the ages of 20-30 years (55\%) and the least age range of 41 and above $(5 \%)$. The participants were majorly from Nigeria $(55.5 \%)$ and India $(43.0 \%)$. Since the purpose of the study was to 
understand the participants' perceptions toward science, technology and law, we focused on participants from 3 major academic fields of study-Law (41.5\%), Science and Technology (43.5\%) and others (15.1\%)(Table 1).

Table 1: Socio-Demographic characteristics of respondents

\begin{tabular}{lll}
\hline Items & Category & Percentage (\%) \\
\hline Gender & Male & $111(55.5 \%)$ \\
Age & Female & $89(44.5 \%)$ \\
& Less than 20 & $25(12.5 \%)$ \\
& $20-30$ & $110(55 \%)$ \\
& $31-40$ & $55(27.5 \%)$ \\
Country & 41 and above & $10(5 \%)$ \\
& India & $86(43.0 \%)$ \\
Field of education & Nigeria & $110(55.0 \%)$ \\
& Others & $4(2.0 \%)$ \\
& Law & $83(41.5 \%)$ \\
& Science & $87(43.5 \%)$ \\
& Technology & \\
& Social Science $\&$ & $30 \quad 15.1 \%)$ \\
& Management & \\
\hline
\end{tabular}

Hypothesis 1: There is no significant difference between male and female's awareness of science, Technology and law.

Science was defined as observation and experimentation (55\%), life (21.5\%) and body of knowledge about a particular subject $(21.5 \%)$, on the other hand, technology was defined as the application of information in the design, production and utilization of goods and services (45\%), science put into practical use (35.5\%) and scientific inventions (18\%). Out of the 200 participants, 114 defined law as rules and guidelines while others as principle if violated results in punishment and as governance (Table 2). There was no significant difference between male and female's understanding of science, technology and law ( $>>0.05$ ). Though based on frequency, male appeared to view science as observation and experimentation, body of knowledge about a particular subject more than females. However, females understood technology as science put into practical use, application of information in the design, production and utilization of goods and services than male. Similarly, female understood law as governance, rules and guidelines than male.

The findings indicate that irrespective of gender difference, the participants were aware and have in-depth knowledge of the subject matter as they expressed science, technology and law in different terms. 
Table 2: Response on participants' understanding of Science, Technology and Law

\begin{tabular}{|c|c|c|c|c|c|c|}
\hline Items & & \multicolumn{2}{|l|}{ Gender } & Total & $\mathbf{F}$ & $\mathbf{p}$ \\
\hline \multirow{5}{*}{ Science } & & & & & & \\
\hline & it is inte & $24(21.070)$ & $19(1 / .1 \%)$ & $43(21.5 \%)$ & 2.042 & 0.100 \\
\hline & $\begin{array}{l}\text { It is a body of knowledge } \\
\text { about a particular subject }\end{array}$ & $16(18.0 \%)$ & $27(24.3 \%)$ & $43(21.5 \%)$ & & \\
\hline & $\begin{array}{l}\text { It is observation and } \\
\text { experimentation }\end{array}$ & $49(55.1 \%)$ & $62(55.9 \%)$ & $111(55.5 \%)$ & & \\
\hline & Others & $0(0 \%)$ & $3(2.7 \%)$ & $3(1.5 \%)$ & & \\
\hline \multirow{4}{*}{$\begin{array}{l}\text { Technol } \\
\text { ogy }\end{array}$} & It is scientific inventions & $15(16.9 \%)$ & $21(18.9 \%)$ & $36(18.0 \%)$ & 0.644 & 0.423 \\
\hline & $\begin{array}{l}\text { It is science put into practical } \\
\text { use }\end{array}$ & $32(36.0 \%)$ & $39(35.1 \%)$ & $71(35.5 \%)$ & & \\
\hline & $\begin{array}{l}\text { It is application of } \\
\text { information in the design, } \\
\text { production and utilization of } \\
\text { goods and services }\end{array}$ & $42(47.2 \%)$ & $48(43.2 \%)$ & $90(45.0 \%)$ & & \\
\hline & Others & $0(0 \%)$ & $3(2.7 \%)$ & $3(1.5 \%)$ & & \\
\hline \multirow[t]{4}{*}{ Law } & It is governance & $12(13.5 \%)$ & $9(8.1 \%)$ & $21(10.5 \%)$ & 3.759 & 0.054 \\
\hline & It is rules and guidelines & $52(58.4 \%)$ & $62(55.9 \%)$ & $114(57.0 \%)$ & & \\
\hline & $\begin{array}{l}\text { It is a principle which, if } \\
\text { violated, results in } \\
\text { punishment }\end{array}$ & $25(28.1 \%)$ & $34(30.6 \%)$ & $59(29.5 \%)$ & & \\
\hline & Others & $0(0 \%)$ & $6(5.4 \%)$ & $6(3.0 \%)$ & & \\
\hline
\end{tabular}

Hypothesis 2: Science, Technology and Law influence and depend on each other.

The participants' awareness was obtained by the strength of their opinion on the influence and dependence of the Science, Technology and Law using Likert scale 1 (Strongly agree) to 5 (Strongly disagree). The attitude and perception of participants are fundamental influence on the degree to which technological orientations occur during learning process. There is significant difference in the participants' responses on the influence and dependence of Science, technology and law $(\mathrm{p}<0.05)$ as it can be seen that over $60 \%$ agreed on the fact that Science, technology and law influence and depend on each other. Though a slight difference was seen with the agreement on law dependence on science and technology, this could be as result of non-clarity on the subject of the matter. About one-third of the participants reported undecided response which could be that they did not understand the question or had no opinion on the subject matter as on how science, technology and law depend or influence each other. 
Table 3: Dependence and influence of Science, technology and Law on each other

\begin{tabular}{|c|c|c|c|c|c|c|c|}
\hline \multirow[t]{2}{*}{ Items } & \multicolumn{5}{|c|}{ Response categories } & \multirow[t]{2}{*}{$\mathbf{t}$} & \multirow[t]{2}{*}{$\mathbf{p}$} \\
\hline & 1 & 2 & 3 & 4 & 5 & & \\
\hline $\begin{array}{ll}\text { Science and } \\
\text { technology } \\
\text { depends } \\
\text { Law }\end{array}$ & $\begin{array}{l}48 \\
(24.0 \%)\end{array}$ & $\begin{array}{l}79 \\
(39.5 \%)\end{array}$ & $\begin{array}{l}46 \\
(23.0 \%)\end{array}$ & $\begin{array}{l}25 \\
(12.5 \%)\end{array}$ & $2(1.0 \%)$ & 32.23 & $<0.05$ \\
\hline $\begin{array}{l}\text { Law depends } \\
\text { on science and } \\
\text { technology }\end{array}$ & $\begin{array}{l}14 \\
(7.0 \%)\end{array}$ & $\begin{array}{l}59 \\
(29.5 \%)\end{array}$ & $\begin{array}{l}63 \\
(31.5 \%)\end{array}$ & $\begin{array}{l}51 \\
(25.5 \%)\end{array}$ & $13(6.5 \%)$ & 36.39 & \\
\hline $\begin{array}{l}\text { Science and } \\
\text { technology } \\
\text { influences Law }\end{array}$ & $\begin{array}{l}38 \\
(19.0 \%)\end{array}$ & $\begin{array}{l}92 \\
(46.0 \%)\end{array}$ & $\begin{array}{l}52 \\
(26.0 \%)\end{array}$ & $\begin{array}{l}16 \\
(8.0 \%)\end{array}$ & $2(1.0 \%)$ & 39.91 & \\
\hline $\begin{array}{l}\text { Law influences } \\
\text { science and } \\
\text { technology }\end{array}$ & $\begin{array}{l}38 \\
(19.0 \%)\end{array}$ & $\begin{array}{l}96 \\
(48.0 \%)\end{array}$ & $\begin{array}{l}49 \\
(24.5 \%)\end{array}$ & $\begin{array}{l}16 \\
(8.0 \%)\end{array}$ & $1(0.5 \%)$ & 35.81 & \\
\hline
\end{tabular}

Hypothesis 3: The impact of Science, Technology and Law in the society is not significant

Exploring the findings in Table 4, it revealed that science and technology do not necessarily make legal processes and the society unresponsive to several issues. The non-explicit link between unresponsiveness in the society and science and technology was stated by less than two-third of the participants (57\%). Majority of the participants indicated that there is no relationship between science and technology and unresponsiveness of the society as regards legal processes. Eighty-five percent $(85 \%)$ agreed that there is need for frequent legislation upon matters pertaining to science and technology as they evolve. In order to test the aforementioned hypothesis, we analysed the key concept of the impact of science and technology on legal processes as well as the need for legislation as regards the subject matter in the society. There is significant difference $(\mathrm{p}<0.05)$ in the two aforesaid items.

Table 4: Participants' view on the effect of science, technology and law in the society

\begin{tabular}{lllll}
\hline Items & \multicolumn{1}{c}{ Response } & t & p \\
& Yes & No & & \\
\hline $\begin{array}{l}\text { Science and technology made legal } \\
\text { processes and the society unresponsive to }\end{array}$ & $86(43.0 \%)$ & 114 & 44.7 & $<0.0$ \\
several issues & & $(57.0 \%)$ & 4 & 5 \\
& $170(85.0 \%)$ & $30(15.0 \%)$ & &
\end{tabular}

Hypothesis 4: Science, Technology and Law do not co-exist harmoniously in the society.

Majority of the participants believed that science, technology and law coexist harmoniously in today's world while less than $10 \%$ do not agree to that. This finding also identify that these perceptions are reflected in their views of science, technology and law. However, $18 \%$ participants' lack of 
enthusiasm for opting to be neutral seems to indicate that either they have little understanding of the magnitude of the science, technology and law in the society or little interest in the question or mixture of both would seem likely. It was found that the difference in the participants' response based on their field of education is not statistically significant $(\mathrm{F}=0.742, \mathrm{p}>0.05)$ (Table 5).

Table 5: Coexistence of Science, Technology and Law in the society based on field of education

\begin{tabular}{|c|c|c|c|c|c|}
\hline & $\begin{array}{l}\text { Sum } \\
\text { squares }\end{array}$ & of $\mathrm{df}$ & Mean square & $\mathbf{F}$ & $\mathbf{p}$ \\
\hline $\begin{array}{l}\text { Between } \\
\text { groups }\end{array}$ & 1.484 & 4 & 0.371 & 0.742 & 0.564 \\
\hline Within groups & 97.471 & 195 & 0.500 & & \\
\hline Total & 98.955 & 199 & & & \\
\hline
\end{tabular}

\section{Discussion}

These findings can be interpreted in several ways; when the knowledge of the participant about science, technology and law was measured generally, it revealed that they all have in-depth knowledge of the subjects in diverse ways and when assessed by gender it shows that there is no significant difference in their level of awareness of the subjects by gender. This indicates that majority understands the importance of science, technology and law to the society irrespective of their gender. In conformity with this finding, Oliver (2015) in his review study opined that the world is fully aware of the transforming importance of modern technologies, science and law. On the supposition that Science, Technology and Law influence and depend on each other, the instant finding is in line with that of Tombul and Cakar, (2015) where they observed the influence of technologies on law enforcement agencies and criminals which have remould their attitudes and perceptions both positively and negatively. Forinstance, the innovations in science and technology as aided the effectiveness and efficiency of law enforcement agencies in term of crime mapping, networking, biometrics, fingerprints, facial or speech recognition, DNA, CCTV camera, social media policing, shotspotter detecting system etc. (Tombul and Cakar, 2015). However, the instant study slightly differ from that of Tombul and Cakar, (2015) which focus on police use of technology to combat crimes and one-third of this study participants reported undecided response when asked how science, technology and law depend or influence each other. This could be that they did not understand the question or had no opinion of the subject matter, a gap for further research.

In essence, there is a relationship within science, technology, law and it influence on the society. Science is a product of knowledge that has been accumulated through the centuries. On the other hand, law is a collection of wisdom that has been framed, modified and compiled through ages, which is 
amended to suit the necessities of times, subsequently transferring development in science and thereafter, technology. Law has become more complex, as well as more systematic and rational, with the emergence of big businesses, organisation of labour, creation of a world market, communications between countries and increasing of population (Hibbitts, 2010; Bakshi, 1995).

Science is truth while law is justice. Science is the cause while law is the effect. Science provides progress while law provides process. Science studies the morphology of the human society while law emphasizes the transformation in human ideals.

Both legal practitioners and scientists would equally agree to the assertion that law and science are vastly different, both in their goals and end results. However, both branches of study have a few, often overlooked, things in common. Both of them influence and are, in turn, influenced by public processes and rational thoughts. Both of them reflect reality and in some ways, each other. Both are responsive to the needs of the society, giving birth to new innovations or legislations, as need be. Science proceeds upon a set of natural laws and law, when studied as an anthropological document, in its strictest sense, becomes a science (Silbey, 2008). So much is the interdependence of the two subjects over one another that jurists and scholars have, in recent time, begun to devote more attention towards how they reflect the developments that happen in each other (Palmerini, 2014).

Similarly, there are several points of contact between law and science. New developments in science and technology prove useful in court proceedings or while carrying out judicial orders. Website Filters etc., help in achieving a legal goal or securing better justice (Hibbitts, 2010; Cockfield, 2004). Scientific activities too, are regulated by legal provisions.

The impact of law in science and technology does not merely influence their development and extent, but also the circumstances, conditions and utilities with which they are applied in a society (Marchant et al., 2011). For example, nuclear bombs, robots, drones, unmanned flying objects and other military devices raise legal and ethical questions regarding whether their use is proper and if so, to what extent. Likewise, there is technology today that enables us to identify the sex of a baby, and whether or not it will have any abnormalities, at increasingly earlier stages in the pregnancy (Moses, 2007). Science has even made it possible to abort a baby without causing any harm to the mother. If uncontrolled, the use of such technology can lead to its widespread misuse, in what can then only be explained as a kind of autonomy.

As such, science and technology without law is more like a child without the parent. The former requires the latter to control them and harness their utility, so as to benefit humanity to the maximum extent with the minimum possible casualties. And where need has arisen, the law of the land 
has been modified, to protect the vulnerable or prevent harassment or abuse of processes. Where science has made life easier and allowed the common man to pursue concepts like ethics and aesthetics, it has also placed us in a position to be able to destroy ourselves. Case in point, there has been a recent surge in IT and cyber crime related legislations, with the growing culture of active online presence and Internet (Varma and Khan, 2013). Previously, the activities of numerous large companies, inland and overseas, were curbed in order to encourage them to adopt universal standards of labour, wages, environmental compatibility, corporate social responsibility and the like, in keeping with the guidelines of the World Trade Organisation (WTO). Intellectual Property rights, that is, copyright and patent rights have aided reformation which prevent companies from fitting their case into one of the pigeon holes, and thus allow them to reap the fruits of theirs and others' hard work.

Technology houses enormous potential to turn the tides of human prosperity and well-being. In essence, it is a double edged sword where it can make one's life easier and on the other hand interfere with the person's rights to privacy and personal liberty. Unless those rights are legally, secured, and apparently, the role of law in assessing the merits and demerits of every little advancement in the field of science and technology, coupled with incorporating its acceptance becomes highly essential. In other words, law is the weapon that can be used to put a check on the disastrous potential of technology. The same was reiterated by the International Society for Technology in Education, when it said that teachers must impart legal and ethical practices unto their students, while teaching them how to use technology (Akcay, 2008). In India, the Information Technology Act, 2000, is the first legislation that focuses broadly on dealing with issues related to cybercrime, e-commerce and the like.

For decades, law and science have been allies, as their primary and ultimate purpose is to arrive at the truth. This makes it imperative for lawyers and law students to be well-informed of technological advancement, which contrarily, is the case. We have an education system that focuses more on the law of technology than it does on the technology of law. Then there is also the issue that law, as a niche, is conservative. However, in recent times, science and technology have had a major impact on law. Patent law, for example, depends largely on scientific theories and explanations. Intellectual property law, on which science has a huge impact, is a rapidly growing niche. But as such, legal process tends to stay away from scientific processes, unless it needs to reach a conclusion about something. And thus, when it is used in courtrooms, and subject to various interpretations and rules, its impartiality and knowledge tend to get defeated. This can work both ways; as legal rules can be twisted with each scientific change or technological development, 
therefore altering its utility and identity consequently making them unascertainable, over or under-inclusive or even obsolete. For example, initially, the opinion of experts was inadmissible in as testimony until a need was felt to explain that, by specialised mental and physical equipment, what ordinary human beings cannot perceive. So much has this dependence on technology increased, that China and USA have reported using software that calculates the punishment and dispenses justice, based on a few inputs (United States v. Booker, 2005).

Scientific research impacts law even when they do not impact science directly. Perhaps they apply to basic scientific principles that contribute in developing new theories, legislations or principles. Consequently, a change is needed in the way the society perceives the relationship between law and science. It is no longer sufficient to be lawyerly equipped with knowledge of all legislations and court processes - the need of the hour is to gather scientific information, analyse problems, communicate ideas, apply principles of cognitive science and explore the potential of new technology. This will ensure lawyers add more value to the legal profession, by advancing better drafting skills, pitching services to clients and gathering evidence in an organised manner.

Equally, technology has had massive impact on different aspects of law. A legal research is incomplete today, without referring to databases like Westlaw or LexisNexis. Archives such as SSRN and Berkeley's are important sources of legal journals. While law remain surrounded by technology to the extent that its fundamental nature is technology (Kotenko and Malko, 2019). It was framed, written and documented, only after invention of the printing press. Technology has given law extended authority over the virtual dimension (Berkowitz, 2005). Legal education is largely dependent on PPTs, PDFs, projectors, virtual classrooms, databases, online bare acts etc., to give students a practical edge. Even mooting is an activity that depends largely on the use of technology. Communication technology and Information Technologies are not just to be used within, but also outside the classroom. The art of collecting, organising and emanating information, in increasingly innovative ways, is something that every law student must perfect, in order not to fail as a student as well as a professional. Court processes, right from the displaying of the hearing list to recording the judgement, is by the use of technology at various stages and in various forms.

However, the influence of science and technology is seen in almost everything, but less consideration is been given to law. Meanwhile, one can hardly come across a report on the current legal development without finding references to the changes caused and challenges posed by emerging technologies. Case in point, science and technology form the ends, means, nature and structure of 
international law: a few treaties regulating the use of technologies ${ }^{11}$, guaranteeing of freedom of research in the high seas ${ }^{12}$, in Antarctica, ${ }^{13}$ and in outer space; ${ }^{14}$ and efforts to secure protection for intellectual property ${ }^{15}$. The point is that each time there are advances in technology as is the case with electronic banking existing legal rules must be stretched to cover such new cases pending when the legislature will step in with relevant specific legislation. We expect the same case scenario regarding electronic banking, there is little or no remedy available to victims. ${ }^{16}$ Another latest advances in technology is the aspect of electronic generated evidence in court which is central to judicial accountability and confidence building in the administration of justice. The peculiarity of the challenges faced with proof of electronic transactions and electronically generated evidence, stem from the fact that we are dealing with paperless transactions, which transactions by nature restrict the use of rules of proving documentary evidence (Osinbajo, 2011). Whether the Sale of Goods law will even apply to the sale of music in online transactions is debatable given its dematerialisation from tangibility to intangibility (Kanyip, 2005). As far back as 1969, the Supreme Court of Nigeria could state in Esso West Africa Incorporation v. Oyagbola, (1969) restated in Yesufu v. African Continental Bank Ltd, (1976) and by the Court of Appeal in Trade Bank Plc v. Chami, (2003) that:

The law cannot be and is not ignorant of modern business methods and must not shut its eyes to the mysteries of the computer.

\footnotetext{
11 See, e.g., Agreement on the International Telecommunications Satellite Organization, opened for signature Aug. 20, 1971, entered into force Feb. 12, 1973, 23 UST 3813, TIAS No. 7532 (1971) (“Intelsat Agreement"); Chicago Convention on International Civil Aviation, opened for signature Dec. 7, 1944, 61 Stat. 1180, TIAS No. 1951, 15 UNTS 296 ("ICAO Convention"); Convention on International Liability for Damage Caused by Space Objects, opened for signature Mar. 29, 1972, entered into force Sept. 1, 1972, 24 UST 2389, TIAS No. 7762, 961 UNTS 187 ("Space Objects Convention"); Statute of the International Atomic Energy Agency, opened for signature Oct. 26, 1956, entered into force July 29, 1957, 8 UST 1093, TIAS No. 3873, 276 UNTS 3, amended, Oct. 4, 1961, 14 UST 135, TIAS No. 5284, 471 UNTS 334 ("IAEA Statute"); Treaty Banning Nuclear Weapons Tests in the Atmosphere, in Outer Space, and under Water, opened for signature Aug. 5, 1963, entered into force October 10, 1963, 14 UST 1313, TIAS No. 5433, 480 UNTS 43 ("Partial Test Ban Treaty"); Treaty on the Non-proliferation of Nuclear Weapons, opened for signature July 1, 1968, entered into force March 5, 1970, 21 UST 483, TIAS No. 6839, 729 UNTS 161 ("Non-Proliferation Treaty"); Treaty on the Prohibition of the Emplacement of Nuclear Weapons on Other Weapons of Mass Destruction on the Sea-Bed and the Ocean Floor and in the Subsoil Thereof, opened for signature Feb. 11, 1971, entered into force May 18, 1972, 23 UST 701, TIAS No. 7337, 955 UNTS 115 ("Sea-Bed Treaty")

12 United Nations Convention on the Law of the Sea, $\S \S 87(1)(f), 143,238-65$, opened for signature Dec. 10, 1982, U.N. Sales No. E.83.V.5 (1983), reprinted in 21 INT'L LEG. MAT'LS 1261

13 Antarctic Treaty, arts. I, II, opened for signature Dec. 1, 1959, entered into force June 23, 1961, 12 UST 794, TIAS No. 4780, 402 UNTS 71

${ }^{14}$ See, e.g., Treaty on Principles Governing the Activities of States in the Exploration and Use of Outer Space, Including the Moon and Other Celestial Bodies, arts. I, IX, opened for signature Jan. 27, 1967, entered into force Oct. 10, 1967, 18 UST 2410, TIAS No. 6347, 610 UNTS 205 (“Outer Space Treaty”)

15 See, e.g., Berne Convention for the Protection of Literary and Artistic Property, original version opened for signature Sept. 9, 1886, current version opened for signature July 24, 1971, 25 UST 1341, TIAS No. 7868, 828 UNTS 221; Patent Cooperation Treaty, opened for signature June 19, 1970, entered into force Jan. 24, 1978, 28 UST 7645, TIAS No. 8733. See generally Symposium, Fundamentals of International Copyright: The Impact of Berne, 8 CARDOZO ARTS \& ENT. L. REV. 1 (1989)

${ }^{16}$ See A. B. Mahmoud, op. cit and the story, -EFCC Smashes Syndicate of ATM Card Duplicators - Bank Staff Arrestedll in Sunday Trust Newspaper of August 16, 2009.
} 
In essence, Advances in technology has rendered some laws obsolete such as; res ipsa loquitor rule, without prejudice rule etc. Another area to take cognizance of is Data Protection Law, the thing to note is that the law has often lacked behind developments in technology especially in most developing countries e.g. Nigeria.

As much as law needs technology, not everything is advantageous. Sometimes, technology proves to be a handful from a legal point of view. It has the capacity to disrupt most students, in pursuance of their education, by proving as an unnecessary distraction for example, the use of mobile phones while lectures are ongoing, and while driving or cooking etc. Then, there is the problem that nobody monitors the authenticity of what is uploaded in the virtual realm. In fact, modern technology shapes and redesigns the world to the extent of tying people to a life of technologies (Oliver, 2015). However, Law is slow to imbibe the changes that take place in the society, whereas technology moves at a rapid pace (Bakshi, 1995). Not only does it sometimes make it difficult to keep up with, but it also leaves the public and the society confused about their rights. Likewise, technology cannot be curtailed within the bounds of geographical boundaries; it is universal. Law, on the other hand, is nation-specific or territorial in nature. Hence, this makes it difficult to legislate upon cross-country or international disputes. There is also the danger of falling prey to frivolous technology in the guise of keeping the law updated. And as such, technology makes it very easy to bypass laws that are framed to check such behaviour.

All these analyses do not imply that law, science and technology cannot co-exist together. They have and will continue to be a distinctive integral part of this world. It is not so much a choice we have, than it is, a necessity. Were there recurring conflicts between the three, of an unsalvageable nature, each would lose it significance and utility, in part or in whole. Science and technology, after all, explain human nature and give answers to the various questions surrounding the physical world. At best, they form the basis, foundation, and need to have certain laws. At worst, they help explain certain legal provisions. Both of these phenomenon are being explored actively by legal practitioners.

\section{Conclusion and Recommendations}

The knowledge and perception of students of selected universities in Nigeria and India about the relationships between Science, Law and Technology regarding its advancement and effect on human endeavour or behaviour was examined, as well as the disadvantages of such technological advances to law. In addressing this objective, four hypotheses were raised and the authors found that there is no significant difference between the understanding of male and female knowledge of science, technology and law 
as to awareness. With respect to the dependence or influence of the three subjects on each other, the participants had no significant opinion on the subject matter and its impact on the society is also not significant. However, majority of the participants are of the view that there is need for the update of legislations as science and technology evolve and that science, technology and law coexist harmoniously in today's world.

From the foregoing, we recommend the followings:

- This research endorses the frequent update of our laws so as to meet up with the latest advances in science and technologies especially in terms of- picking calls on motions or driving (road safety), visiting social medias during class lectures (Educational board), etc.

- Proper education of people by schools, government and Non Governmental Organisation on the advancement of technologies and it negative effects to the society.

- Not all advancement in technology must be followed by an amendment in the legislature, without assessing its utility and the risks associated with it.

- While technology can be a useful tool for most students, its use must be regulated and limited to what is necessary.

- Awareness must be raised among legal practitioners and scientists alike that law and science are inter-related and can exist without being a threat to each other.

- The society must be made aware that science and law support each other in their individual pursuits and, as such, are equally essential for a progressive society.

Apparently, law, science and technology have their own importance and must conjure up a harmonious path to tread, so that the society can achieve the optimum rate of progress.

\section{Limitations of Study}

The narrow scope of participants (selected students from science, technology and law) used in measuring the influence of science and technology in law and vice-versa could vary the results if participants were drawn from practitioners with relevant experience on the actual interplay between science, technology and law randomly. Due to the sample size and the sample frames used for data collections there may be discrepancies if a larger sample is drawn from a particular population in lieu of the two selected countries. In terms of comparability, this study could be limited because few studies have been conducted in this regards based on the authors' knowledge. However, the method of data collection could pose as a restraint to this 
research survey, if the one-on-one method is adopted for better understanding of the subject matter as opposed to the online data collection method the findings might vary. The non-probability sampling method used could also have effect on the results if conducted with probability sampling distribution.

\section{Conflict of Interest}

The authors declare that there is no conflict of interest regarding the publication of this article and the authorship.

\section{References:}

1. Aina-Pelemo, A. D., and Saluja, S. (2018). Comparative Analysis of Sex-Selection in Nigeria and India. International Journal of Humanities and Social Science Studies, 4(6), 70-88. doi:10.29032/ijhsss. v4. I6.2018.70-88

2. Aina-Pelemo, A. D., Mehanathan, M. C. and Kulshrestha, P. (2018). Sexual Harassment at Workplace: Judicial Impact in Nigeria and India. Indian Journal of Law and Human Behaviour, 4(2), 208-221. doi: http://dx.doi.org/10.21088/ijlhb.2454.7107.4218.8

3. Akcay, D. B. (2008). The Relationship Between Technology and Ethics; From Society to Schools. Turkish Online Journal of Distance Education, 9(4), 120-127.

4. Albert, M., and Laberge, S. (2007). The Legitimation and Dissemination Processes of the Innovation System Approach - The Case of the Canadian and Quebec Science and Technology Policy. Science, Technology \& Human Values, 32(2), 221-249. https://doi.org/10.1177/0162243906296854

5. Andrade, T. H., Silva, L. R. and Gitahy, L. (2013). New Policies for Science and Technology and the Impacts on Public Research Institutes: a Case Study in Brazil. Brazilian Political Science Review, 7(2), 37-61.

6. Atchison and C.R.R. Co. v. U.S. 15 Court of Claims (per Davis J.); Sarkar Evidence (1971), page 496

7. Bakshi, P. (1995). Science, Technology and Law. Institute's Journal, 3, 1-13.

8. Beebe, B. (1999). Law's Empire and the Final Frontier: Legalizing the Future in the Early Corpus Juris Spatialis. Yale Law Journal, 108(7), 1737-1773. doi: 10.2307/797449

9. Berkowitz, R. (2005). The Gift of Science: Leibniz and the Modern Legal Traditions. Harvard University Press, Mass: Cambridge, pp. xviii 214. 
10. Bernstein, G. (2004). Accommodating Technological Innovation: Identity, Genetic Testing, and the Internet. Vanderbilt Law Review, 57(3), 963.

11. Berson, M. J., Bersn, I. R., \& Ralston, M. (1999). A Response to 'Separating Wheat from Chaff'. Social Education, 63(3), 160-161.

12. Blakey, E. (2000). One World, One Internet? (E-commerce News) Accessed June $\quad 3^{\text {rd }}$, 2019 from https://www.google.com/search?q=Blakey,+E.+(2000).+One+World, + One+Internet?+Ecommerce+News\&tbm $=$ isch\&source $=$ univ\&sa $=\mathrm{X}$ \&ved=2ahUKEwjKmZrmrM7iAhVxShUIHUa2CbAQsAR6BAgFE AE\&biw $=1267 \&$ bih $=697>$

13. Burke, J., Bergman, J., and Asimov I. (1985). The Impact of Science on Society. Prepared by Langley Research Center, Scientific and Technical Information Branch, National Aeronautics and Space Administration Washington, DC. Accessed June $3^{\text {rd }}, 2019$ from https://history.nasa.gov/sp482.pdf

14. Cockfield, A. (2004). Towards a Law and Technology Theory. Manitoba Law Journal, 30(3), 383-415.

15. Dellapenna, J. W. (2000). Law in a Shrinking World: The Interaction of Science and Technology with International Law. Villanova Public Law and Legal Theory Research Paper Series.

16. Easterbrook, F. H. (1996). Cyberspace and the Law of the Horse. The University of Chicago Legal Forum, 207-216.

17. Ekong, E. E. (2006). Sociology of Health and Medicine. Uyo: Dove Educational Publishers.

18. Feldman, R. (2009). The Role of Science in Law. London: Oxford University Press.

19. Godwill, E. A. (2014). Science and Technology in Africa: The Key Elements and Measures for Sustainable Development. Global Journal of Science Frontier Research: G Bio-tech and Genetics.

20. Goldberg, S. (1987). The Reluctant Embrace: Law and Science in America. Georgetown Law Journal, 75, 1341.

21. Hibbitts, B. J. (2010). The Technology of Law. Law Library Journal, 102(1), 101-115.

22. Holmes, O. W. (1899). Law in Science and Science in Law. Harvard Law Review, 12(7), 443-463.

23. Huber, P. (1991). Galileo's Revenge: Junk Science in the Courtroom. Basic Books.

24. Information Technology Act, (2000). Accessed $18^{\text {th }}$ May, 2019 from: https://indiacode.nic.in/bitstream/123456789/1999/3/A2000-21.pdf 
25. Janis, M. D., \& Smith, S. (2006). Obsolescence in Intellectual Property Regimes. Legal Studies Research Paper, 05-48. University of Lowa, Lowa City.

26. Jasanoff, S. (1995). Science at the Bar: Law, Science and Technology in America. Harvard University Press: Cambridge.

27. Katsh, M. E. (1989). The Electronic Media and The Transformation of Law. Oxford University Press: ...pp 347.

28. Kaut, J. A. (2000). Congress Mulls over E-Commerce Measures on Database Protections: Consumer Privacy. 68USLW2475.

29. Kanyip, B. B. (2005). Consumer Protection in Nigeria: Law, Theory and Policy (pp 143 - 146). Abuja: Rekon Books Ltd.

30. Kotenko, M. and Malko, A. (2019). Legal Techniques and Technology as the Most Important Factors for the Sustainable Development of the Societal Legal System. doi: 10.21684/2412-2343-2019-6-2-132-153

31. Latour, B., and Woolgar, S. (1979). Laboratory Life: The social construction of scientific facts. Beverly Hills: Sage Publications.

32. Marchant, G. E., Allenby, B., Arkin, R., Barrett, E. T., Borenstein, J., Gaudet, L. M., Kittrie, P. L., Lucas, G. R., O’Meara, R., and Silberman, J. (2011). International Governance of Autonomous Military Robots. Columbia Science and Technology Law Review, 12(272), 227-315.

33. Merritt, D. J. (2007). Legal Education in the Age of Cognitive Science and Advanced Classroom Technology. Public Law and Legal Theory Working Paper Series No. 94.

34. Moreira, N. V., Almeida, F. A., Cota, M. F., \& Sbragia, R. (2007). A inovacao tecnologica no Brasil: os avancos no marco regulatorio e a gestao dos fundos setoriais. Revista de Gestao USP, 31-44.

35. Moses, L. B. (2007). Why Have a Theory of Law and Technological Change? Minnesota Journal of Law, Science \& Technology, 8(2), 589606.

36. Oliver, C. (2015).Critical Analysis of Ubiquitous Computing based on Martin Heidegger's Notions of World and Technology. European Scientific Journal, 11(11), 25-39.

37. Palmerini, E. (2014). The Interplay between Law and Technology. 7 24. Accessed June $3^{\text {rd }}, \quad 2019$ from http://www.robolaw.eu/RoboLaw_files/documents/Palmerini_Intro.p df

38. Price, M. E., and Duffy, J. F. (1997). Technological Change and Doctrinal Persistence: Telecommunications Reform in Congress and the Court. Columbia Law Review, 97(4), 976-1015. doi: $10.2307 / 1123314$ 
39. Ruggie, J. G. (1975). International Responses to Technology: Concepts and Trends, International Organisation. Cambridge University Press, 29(3), 557-583.

40. Sandstrom, G. (2012). Laws of Media: The Four Effects. Social Epistemology Review and Reply Collective, 1(12), 1-6.

41. Silbey, S. S. (2008). Law and Science I: Epistemological, Evidentiary and Relational Engagements. Ashgate Publishing Limited.

42. Soberg, S. (2001). Science and Technology in Education - Current Challenges and Possible Solutions. Meeting of European Ministers on Education and Research.

43. Sorensen, K. H. (2004). Cultural Politics of Technology: Combining Critical and Constructive Interventions. Science, Technology and Human Values, 29(2), 184-190. https://doi.org/10.1177/0162243903261944

44. Technological and Legal Developments in Intellectual Property. (n.d.). WIPO Intellectual Property Handbook: Policy, Law and Use, 434-460.

45. Tombul, F. and Cakar, B. (2015). Police use of Technology to Fight Against Crime. European Scientific Journal, 11(10), 286 - 296.

46. Tribe, L. (1989). The Curvature of Constitutional Space: What Lawyers Can Learn from Modern Physics. Harvard Law Review, 103(1), 14-15. doi:10.2307/1341407

47. United States v. Booker and United States v. FanFan, (2005) 543 U.S. 220 Supreme Court of United States, January 12.

48. Varma, T. N., and Khan, T. N. (2013). Curbing Cyber Crimes by Indian Law. SSRN Electronic Journal, 1(3), 40-51. doi: $10.2139 / \mathrm{ssm} .2922365$

49. Vergragt, P. J. (2006). How Technology Could Contribute to a Sustainable World. GTI Paper Series.

50. Weiss, C. (2005). Science, Technology and International Relations. Technology in Society, 27, 295-313.

51. Osinbajo, Y. (2011). In Afe Babalola (Eds.), Law \& Practice of Evidence in Nigeria: Electronically Generated Evidence (pp. $243-$ 273).

52. Osuala, E. C. (2001). Introduction to Research Methodology ( $3^{\text {rd }}$ Ed.) Onitsha: Africana-Feb Publishers, Ltd. 